\title{
The Support System for Small and Medium Business: Case of Poland
}

\author{
Pawel Dec ${ }^{1} \&$ Piotr Masiukiewicz ${ }^{2}$ \\ ${ }^{1}$ Institute of Corporate Finance and Investment, Warsaw School of Economics, Warsaw, Poland \\ ${ }^{2}$ Institute of Value Management, Warsaw School of Economics, Warsaw, Poland \\ Correspondence: Pawel Dec, PhD, Institute of Corporate Finance and Investment, Warsaw School of Economics, al. \\ Niepodleglosci 162, 02-554 Warszawa, Poland. Tel: 48-564-0000. E-mail: paweldec@gmail.com
}

Received: July 31, 2014

doi:10.5430/rwe.v5n2p150
Accepted: August 20, 2014

Online Published: August 30, 2014

URL: http://dx.doi.org/10.5430/rwe.v5n2p150

\begin{abstract}
This article is about system support for small and medium-sized businesses (SMEs) in Poland. According to the authors running this type of business still faces a number of barriers, not only administrative and legal, but also in mentality. The authors present in-depth statistical research of the SME sector in Poland, presenting among other things, the revenues, contribution to GDP, and the demographics of bankruptcy of companies in this sector. These data helped to show how great the importance of the SME sector in Poland is. The key research question was to identify the main barriers to systemic and behavioural affecting the operation of SMEs. The authors also critical evaluation of the Second chance program implemented in the European Union, and is primarily concerned with making the business a second time after the bankruptcy of the previous activities of the company and the processes of recovery and restructuring of companies in crisis.
\end{abstract}

Keywords: small and medium-sized enterprises, business support system, operating conditions, financing

\section{Introduction}

In many countries, small and medium-sized enterprises generate half or more of GDP; hence the importance of constant concern of state authorities to provide good conditions for the development of this sector.

In Poland, in the period of 25 years developing a market economy is a system of institutional support for SME development, and small and medium-sized companies are leaders in some sectors of the economy. Polish SME sector is well presented at the economic performance against other countries. The development of private enterprise was made possible thanks to the wide transformation of the economy and privatization, but also thanks to the support of highly developed Western countries. However, there are still administrative and financial barriers that inhibit the development of SMEs. In the context of the recent financial crisis has increased the importance of the repair businesses - in the EU implemented the Program "Second Chance" for entrepreneurs.

The purpose of this article is to assess the level of SME development in Poland, its determinants and gap analysis of the institutional system of support.

\section{Development of SME and Main Determinants}

The main determinants of functioning and development of SMEs in Poland include deep changes the political system, foreign assistance and hard work and entrepreneurship of Polish citizens. (Zukowski, 2014) In particular, the following terms and conditions determining the development of the SME:

- Political and economic transformation; including extensive privatization of state assets,

- Implementation of government support programs for SMEs, including the construction of a system of institutional support,

- Significant financial and advisory support in Western Europe and North America, including structural adjustment programs of the European Union,

- Broad participation in the education business (higher education, business courses, et al.)

- The functioning of SME mostly based on their own financial resources (more than $70 \%$ of companies do not have external debt),

- High entrepreneurial activity, an increase in the social status of entrepreneurs and recognition for private business, 
- Flexibility for employees,

- The lack of impact of the direct effects of the subprime crisis on the Polish economy. (Dec\& Masiukiewicz, 2014)

In the first years of transition the important role played by financial and advisory support U.S. and other western countries. It was established Polish-American Enterprise Fund, launched the World Bank credit lines for SME Bank was established Polish-Canadian. After the Polish accession to the EU are important support framework programs of EU subsidies for SMEs, designed to level the playing field and the acceleration of convergence. Poland is still a beneficiary of the EU.

The growing importance of international trade is increasing the role of chambers of commerce such as the Polish-Canadian Chamber of Commerce, Canada-Poland Chamber of Commerce (Montreal and Toronto), Canada-Poland Business Club, Polish organizations and others. Support for business are an MBA (for example, English-Canadian MBA Study in Warsaw School of Economics).

Polish entrepreneurs, experienced by the economic transformation of the $90 \mathrm{~s}$ are better prepared to deal with difficulties than many companies from countries where no similar problems. Polish workers turned out to be more flexible - accepting lower wages and incurring other austerities in order to create and maintain jobs. (Zukowski, 2014)

High dynamics of development of SMEs in Poland confirmed by the following statistics. Table 1 shows the number of small and medium enterprises which are established and liquidated in the years 2003-2011. In 2011, began operations 408008 companies, of which 407,892 (thus 99.97\% of all firms) were the SME companies. This shows the important role this sector plays in economic development in Poland.

Table 1. Demographics of small and medium-sized enterprises in Poland

\begin{tabular}{lllllllllll}
\hline \multirow{2}{*}{ Year } & \multicolumn{1}{c}{ Micro } & \multicolumn{9}{c}{ Small } \\
\cline { 2 - 10 } & Registered & Established & Liquidated & Registered & Established & Liquidated & Registered & Established & Liquidated \\
\hline 2003 & 3463245 & 265946 & 148202 & 144618 & 7569 & 3888 & 30106 & 1071 & 978 \\
\hline 2004 & 3485970 & 223863 & 204979 & 149159 & 4144 & 3723 & 30029 & 484 & 911 \\
\hline 2005 & 3528198 & 282517 & 228171 & 154643 & 6144 & 4059 & 30174 & 651 & 665 \\
\hline 2006 & 3548677 & 311732 & 283271 & 156408 & 4409 & 3742 & 30219 & 448 & 451 \\
\hline 2007 & 3599259 & 309248 & 253100 & 159426 & 4317 & 3348 & 30266 & 442 & 490 \\
\hline 2008 & 3666481 & 334812 & 257717 & 164795 & 5180 & 5166 & 31225 & 526 & 988 \\
\hline 2009 & 3672853 & 397114 & 377920 & 170182 & 5240 & 4726 & 31648 & 381 & 612 \\
\hline 2010 & 3876119 & 459270 & 264133 & 173099 & 5838 & 3963 & 31670 & 494 & 493 \\
\hline 2011 & 3861352 & 401208 & 412995 & 173449 & 6153 & 5498 & 31329 & 531 & 734 \\
\hline
\end{tabular}

Source: Own studies based on www.parp.gov.pl, Retrieved April 30, 2014.

Figure 1 shows that almost 50\% of GDP is generated by the SME sector in Poland It is over two times more than generate large enterprises. This proves that with the continued strong position in the sector of small and medium-sized enterprises in Poland.

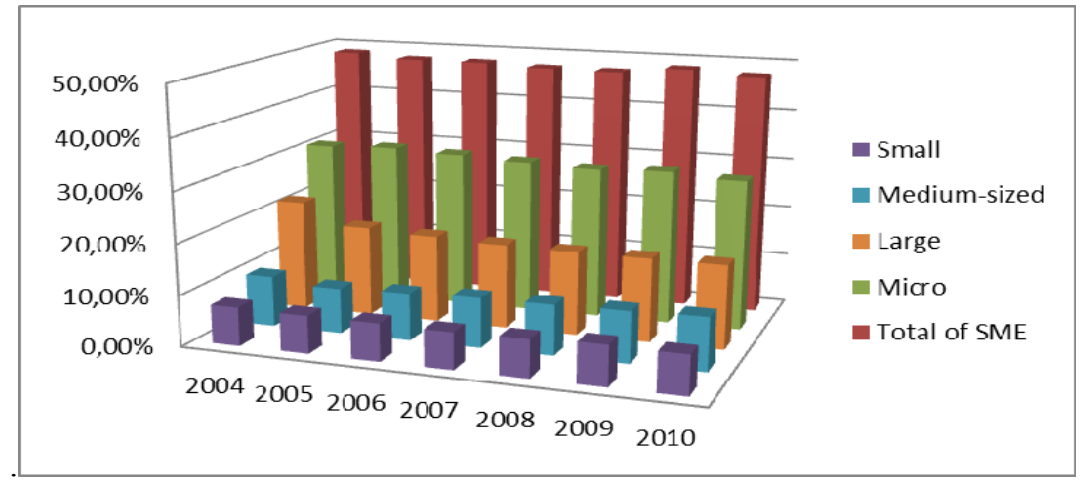

Figure 1. Shares of individual groups of enterprises in GDP in Poland in the years 2004-2010

Source: Own studies based on www.parp.gov.pl, Retrieved May 15, 2014 
In comparison with other countries, Polish SME sector ranks in the midfield. The leader is definitely Norway, where this sector generates almost $60 \%$ of GDP. (See Figure 2).

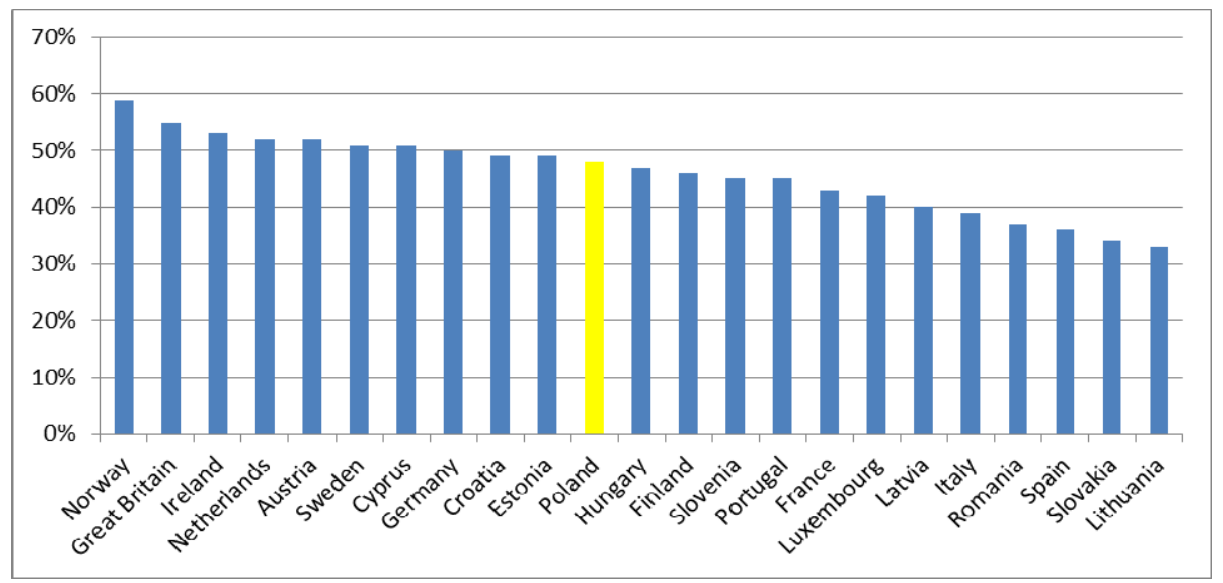

Figure 2. The share of the SME sector in GDP in different countries in 2009

Source: Own studies based on www.parp.gov.pl, Retrieved May 10, 2014

Revenues of SMEs are smaller than the large enterprises in Poland, however, the cumulative value of this sector is much higher than the income obtained by the largest companies. In 2010 were higher by almost $30 \%$.

In summary, the state and dynamics of the SME sector in Poland can be considered good; which is confirmed by data from the World Bank report, published last year. (CSES, 2013)

\section{Business Support Systems and Solutions}

In recent years, Poland has crystallized and strengthened system of institutional support for the development of SMEs. It consists of laws, government agencies, local government and private. The main center concept, creating support programs and the distribution of EU subsidies is the Polish Agency for Enterprise Development (PARP). The reference system for SME support institutions in Poland shows Figure 3.

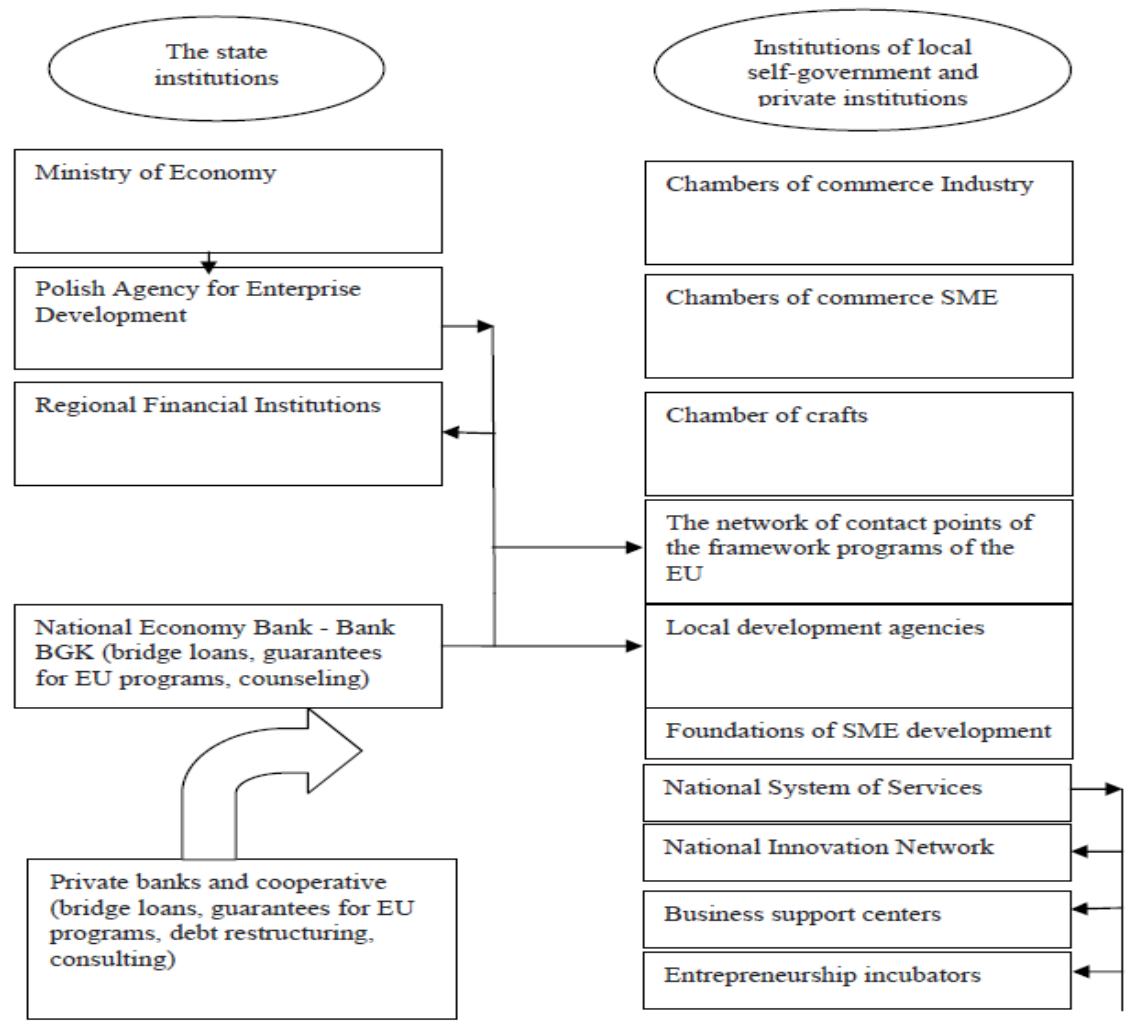

Figure 3. Framework system of SME support institutions in Poland 
For the operation and development of SME important role has been played by the system leverage both domestic and foreign. Figure 4 presents a framework system of financial support for small and medium-sized enterprises in Poland.

\begin{tabular}{|c|c|}
\hline Type financial support & Sources of financing support \\
\hline $\begin{array}{l}\text { Preferential loans with guaranteed } \\
\text { liquidity de minimis of the } \\
\text { Treasury }\end{array}$ & The state budget \\
\hline \multicolumn{2}{|l|}{ Funds for start-ups } \\
\hline \multicolumn{2}{|l|}{ Finansowanie promocji eksportu } \\
\hline $\begin{array}{l}\text { Grants from EU programs for } \\
\text { investments }\end{array}$ & $\begin{array}{l}\text { a) The European Commission } \\
\text { b) the state budget }\end{array}$ \\
\hline $\begin{array}{l}\text { Making space for business } \\
\text { incubators }\end{array}$ & $\begin{array}{l}\text { The budgets of local governments, } \\
\text { foundations of SME }\end{array}$ \\
\hline $\begin{array}{l}\text { Local funds loans and guarantees } \\
\text { for SMEs }\end{array}$ & $\begin{array}{l}\text { 1) private funding } \\
\text { 2) funds from the budgets of local } \\
\text { governments }\end{array}$ \\
\hline $\begin{array}{l}\text { Legal and organizational } \\
\text { consulting }\end{array}$ & $\begin{array}{l}\text { a) funds business chambers } \\
\text { b) budgets of local governments } \\
\text { c) of SME foundations }\end{array}$ \\
\hline Free courses in business & $\begin{array}{l}\text { 1) terrain labor offices of the state } \\
\text { budget } \\
\text { 2) local budgets and foundations }\end{array}$ \\
\hline Funding of new jobs in of SME & $\begin{array}{l}\text { Field offices work from the state } \\
\text { budget }\end{array}$ \\
\hline
\end{tabular}

Figure 4. Framework system of financial support for small and medium-sized enterprises

Source: Own work

The role of education and qualifications for conducting of SME is difficult to overestimate.(Lukasinski, 2013) Poland has a well-developed system of personnel training for business management; including the so-called. family businesses. More than 200 schools of higher learning set up and run their own business in the fields of management and marketing.

The most important of the Polish government in recent years include:

- The simplification of the procedures for establishing companies (including e-registration),

- Preparation of a new Law Repair and Bankruptcy,

- Implement the law on commercial transactions,

- Implementation of the EU program "second chance" for entrepreneurs

- The introduction of free (for one year) of state guarantees for loans liquidity for SMEs

- Support the establishment and development of SME companies from EU grants (de minimis aid) under the Program Innovative Economy

- Implementation of the program "Support for export".

The rapid development of the SME sector would not be possible without investment subsidies from the European Commission (Competitivenes and Innovation Framework Programe). In the years 2007-13 the EU help for SMEs in Poland amounted to EUR 68 billion.

\section{Second Chance Program in the EU and Its Implementation}

Bankruptcy means the economic and social costs to the economy. (Altman and Hotchkiss, 2007) Even though bankruptcy entrepreneur should - with the support of various institutions have a second chance - a chance to re-operate. (European Commission [EC], 2011a) European Commission's approach to bankruptcy cases can be considered revolutionary, because the bankruptcy notice is to be the last resort, if the road exhausted help entrepreneurs. Support SMEs in the development of both the crisis and is aimed at a comprehensive program of the 
European Union - The SBA (Small Business Act) and the guidelines of the "second chance". (Pentor, 2011) Basic legal instruments, financial and organizational support for SMEs are set in EU documents:

- Overcoming the stigma of failure in business - for a second chance. (EC, 2007)

- Community guidelines on State aid for rescuing and restructuring firms in difficulty. (EC, 2004)

- Directive on combating late payment in commercial transactions. (EC, 2011b)

- Regulation creating a European Enforcement Order for uncontested claims. (EC, 2004)

- Regulation establishing a European procedure for small claims. (EC, 2007)

The European Union operates the Enterprise Europe Network. EEN is an extensive network (population of 600 organizations and four thousand. Employees providing information and advice to businesses, including businesses that survived bankruptcy and decide to start a business again. Also in Poland there are business support centers in the EEN. The European Commission believes that a more supportive environment for businesses at risk may prevent failure. Highlighting the problem of the negative effects of business failure and its negative events would help to make the best of human creativity in Europe, boost entrepreneurship and promote innovation and job creation. (Elliot\&Schwartz, 2002)

Poland has implemented all the EU directives in this area, but their effects should wait. The most important activities of the government in recent years include:

- Simplification of the procedures for setting up companies (including e-registration).

- Preparation of a new Law on recovery and insolvency.

- Implement the law on commercial transactions.

- The introduction of free (for one year) of state guarantees for loans liquidity for SMEs.

- Support the establishment and development of SMEs from EU grants (de minimis) under the Innovative Economy Operational Programme.

- The implementation of the program Support for export.

An important gap is the lack of state funds for the repair processes of companies that would support these processes in SMEs. It is also necessary to further simplify the procedures for starting a business and to simplify the tax system. In the light of the World Bank report of 2012 concerning the taxation systems in the world, with respect to its favor for entrepreneurs, Poland was classified in the second hundred in 183 countries. The report IEF (Index of Economic Freedom) in 2012, published by The Heritage Foundation and containing international rating of economic freedom, Poland was only in 64th place.

\section{Economic Barriers of Development}

Leading companies in the SME sector in Poland faces a number of barriers in the system: the tax system, sources of financing, export, and support in crisis and to receive a second chance after bankruptcy. [Masiukiewicz, 2012] Research indicates a low use of leverage, but also companies complain of limited access to external financing. (Masiukiewicz\&Nowak, 2012)

The study of SMEs in 2010 has shown that the risks associated with the crisis were not seen as the most important (See Table 2). High taxes, poor tax system, falling demand and changes in economic conditions were cited by entrepreneurs as a major threat to business.

Table 2. The main threats to the functioning of SMEs

\begin{tabular}{lll}
\hline No. & Type of threat $(\mathrm{N}=1205)$ & Answers (in \%) \\
\hline 1 & The tax system, high taxes & 44.0 \\
2 & No inflow of new customers, declining number of customers & 43.0 \\
3 & The unpredictability of the market, changes in economic conditions & 37.0 \\
4 & Unfair competition & 36.0 \\
5 & Generally strong, excessive competition & 35.0 \\
6 & Delay or suspension of payments from customers & 19.0 \\
7 & Instability regulations & 18.0 \\
8 & Difficulties in obtaining loans & 9.0 \\
9 & Set tenders & 8.0 \\
10 & Lack of staff with appropriate qualifications or skills & 8.0 \\
\hline
\end{tabular}

Source: Own studies based on (Orłowski et al 2010). 
Consulting support is available in EEN or chambers of commerce, (e.g. Chamber of Small and Medium Enterprises in Warsaw). There is in the country a developed structure of consulting firms - company doctors who support the conceptual recovery programs. Lack of a national restructuring fund which, together with bank financing would ensure the survival of the so-called capital for companies in crisis.

Polish Agency for Enterprise Development annually commissions research in the SME sector. In 2011 we conducted a study on bankruptcies. When asked about the kind of support they need entrepreneurs starting a second time a business - most responses of the surveyed entrepreneurs related to counselling support, but financial support definitely yes and probably yes answered $67 \%$ of respondents (See Table 3 ).

Table 3. The types of support they need entrepreneurs who finished a business as a result of bankruptcy and who start next activity

\begin{tabular}{llllll}
\hline No. & Type of support & $\begin{array}{l}\text { Definitely yes } \\
(\%)\end{array}$ & $\begin{array}{l}\text { Probably } \\
\text { yes }(\%)\end{array}$ & $\begin{array}{l}\text { Probably } \\
\text { not }(\%)\end{array}$ & $\begin{array}{l}\text { Definitely not } \\
(\%)\end{array}$ \\
\hline 1 & Advisory support & 48.0 & 38.0 & 12.0 & 2.0 \\
\hline 2 & Training support & 33.0 & 40.0 & 21.0 & 5.0 \\
\hline 3 & Financial support & 29.0 & 38.0 & 24.0 & 9.0 \\
\hline 4 & Psychological suport & 14.0 & 45.0 & 40.0 & 0.0 \\
\hline
\end{tabular}

Source: Own studies based on (Pentor, 2011).

Polish law provides for only one formal path repair procedure and the infrastructure to support these processes is negligible. Quite different solutions are in the European Union. General criticism of entrepreneurs, experts, and judges reported in recent years, justifies a thorough reform of the regulatory environment. (Masiukiewicz, 2012)

Within the research by the Delphic panel (Masiukiewicz, Nowak, 2012), experts generally recognized as the principal treasury institution which should provide financial support to repair enterprises. Respondents considered good form of support to guarantee the various institutions of the state. Indicated, among others. foundations of regional SMEs, PARP and fund guarantees the Treasury. In light of the research cited most frequently reported criterion for granting aid were the objective of the difficulties faced, not masked by the company and an instance of undeserved loss of $30 \%$ of fixed assets as a result of such a disaster.

The great majority of respondents did not allow the possibility of subsidizing companies who are experiencing difficulties due to such mismanagement or deliberate bankruptcy.

A separate issue is the taxation of canceled debt. Banks, on account of outstanding loans are for borrowers past due receivables. So open a recovery procedure aimed at them off. In the absence of prospects for a quick recovery, banks sometimes decide to discontinue all or part of the debt - to support the process of recovery. (Masiukiewicz and Nowak, 2012)

A significant gap is the lack of state funds for the repair processes of companies that would support these processes in the SME sector. It is also necessary to further simplify the procedures for starting a business and to simplify the tax system. In the light of the World Bank report of 2012 concerning the taxation systems in the world, according to the criterion of their favor for entrepreneurs, Poland was classified in the second hundred to 183 countries. (PWC, 2012) Therefore exist a need for a change in the accounting for the valuation of intangible assets. These assets despite the fact that often exceed the value of the assets are not disclosed in the financial statements.

\section{Economic Barriers to Development}

Running a small or medium-sized (SME) enterprises in Poland faces several barriers in the system: the tax system, sources of financing, export, and support in crisis and to receive a second chance after bankruptcy. Research indicates a low use of leverage, but also companies complain of limited access to external financing. (Masiukiewicz, 2012)

The study of SMEs in 2010 has shown that the risks associated with the crisis were not seen as the most important (Table 4). High taxes, poor tax system, falling demand and changes in economic conditions were cited by entrepreneurs as a major threat to business. 
Table 4. The main threat to the functioning of SME companies in Poland during the crisis in the EU (the study in 2010)

\begin{tabular}{lll}
\hline No. & Type of threat $(\mathrm{N}=1205)$ & Answers (in \%) \\
\hline 1 & The tax system, high taxes & 44.0 \\
2 & No inflow of new customers, declining number of customers & 43.0 \\
3 & The unpredictability of the market, changes in economic conditions & 37.0 \\
4 & Unfair competition & 36.0 \\
5 & Generally strong, excessive competition & 35.0 \\
6 & Delay or suspension of payments from customers & 19.0 \\
7 & Instability regulations & 18.0 \\
8 & Difficulties in obtaining loans & 9.0 \\
9 & Set tenders & 8.0 \\
10 & Lack of staff with appropriate qualifications or skills & 8.0 \\
\hline
\end{tabular}
Source: Own studies based on (Orłowski et al 2010)

Consulting support is available in EEN or chambers of commerce, (e.g. Chamber of Small and Medium Enterprises in Warsaw). There is in the country a developed structure of consulting firms - company doctors who support the conceptual recovery programs. Lack of a national restructuring fund which, together with bank financing would ensure the survival of the so-called capital for companies in crisis.

Polish Agency for Enterprise Development annually commissions research in the SME sector. In 2011 we conducted a study on bankruptcies. When asked about the kind of support they need entrepreneurs starting a second time a business - most responses of the surveyed entrepreneurs related to counselling support, but financial support definitely yes and probably yes answered $67 \%$ of respondents (See Table 5).

Table 5. The types of support they need entrepreneurs who finished a business as a result of bankruptcy and who start next activity (research from 2011)

\begin{tabular}{llllll}
\hline No. & Type of support & $\begin{array}{l}\text { Definitely yes } \\
(\%)\end{array}$ & $\begin{array}{l}\text { Probably } \\
\text { yes }(\%)\end{array}$ & $\begin{array}{l}\text { Probably } \\
\text { not }(\%)\end{array}$ & $\begin{array}{l}\text { Definitely not } \\
(\%)\end{array}$ \\
\hline 1 & Advisory support & 48.0 & 38.0 & 12.0 & 2.0 \\
2 & Training support & 33.0 & 40.0 & 21.0 & 5.0 \\
3 & Financial suport & 29.0 & 38.0 & 24.0 & 9.0 \\
4 & Psychological suport & 14.0 & 45.0 & 40.0 & 0.0 \\
\hline
\end{tabular}

Source: Own studies based on (Pentor, 2011).

Polish law provides for only one formal path repair procedure and the infrastructure to support these processes is negligible. Quite different solutions are in the European Union. General criticism of entrepreneurs, experts, and judges reported in recent years, justifies a thorough reform of the regulatory environment.

Within the research by the Delphic panel (Masiukiewicz, Nowak, 2012), experts generally recognized as the principal treasury institution which should provide financial support to repair enterprises. Respondents considered good form of support to guarantee the various institutions of the state. Indicated, among others. foundations of regional SMEs, PARP and fund guarantee the Treasury. In light of the research cited most frequently reported criterion for granting aid were the objective of the difficulties faced, not masked by the company and an instance of undeserved loss of $30 \%$ of fixed assets as a result of such a disaster. Not very optimistic in respect to the background look potentiality of SME financing in Poland (Table 6).

Table 6. The most important form of financing (leverage) in order to support the process of repair companies in the opinion of experts (in \%)

\begin{tabular}{llc}
\hline No. & Forms of financing & In \% \\
\hline 1 & $\begin{array}{l}\text { Credit Guarantee Fund guarantees and government guarantees managed by National } \\
\text { Economy Bank }\end{array}$ & 48 \\
\hline 2 & Loan ssurety without commission by the Polish Agency for Enterprise Development & 40 \\
\hline 3 & Loan surety without commission by regional foundations SME development & 36 \\
\hline 4 & $\begin{array}{l}\text { The loan from a special fund for public-private sanitation targets, preferential interest } \\
\text { rate }\end{array}$ & 24 \\
\hline 5 & Exemption from all taxes for a specified period by the Tax Chamber & 24 \\
\hline 6 & Loan surety without commission by the Industrial Development Agency & 20 \\
\hline 7 & Input capital of the Treasury to the company for the duration of the repair process & 20 \\
\hline 8 & $\begin{array}{l}\text { Loan restructuring of the bank statement with the charge for the interest of the state } \\
\text { budget }\end{array}$ & 16 \\
\hline
\end{tabular}




\begin{tabular}{lll}
\hline 9 & $\begin{array}{l}\text { The loan from the special fund of the state for the purpose of rehabilitation, } \\
\text { preferentially interest rate }\end{array}$ & 12 \\
\hline 10 & Loan restructuring of state bank of charge to interest from the state budget & 8 \\
\hline 11 & The loan in the form of liquid bonds from the state budget & 4
\end{tabular}

Source: Own studies based on (Masiukiewicz\&Nowak 2012)

The great majority of respondents did not allow the possibility of subsidizing companies who are experiencing difficulties due to such mismanagement or deliberate bankruptcy. A separate issue is the taxation of canceled debt. Banks, on account of outstanding loans are for borrowers past due receivables. So open a recovery procedure aimed at them. In the absence of prospects for a quick recovery, banks sometimes decide to discontinue all or part of the debt - to support the process of recovery. A significant gap is the lack of state funds for the repair processes of companies that would support these processes in the SME sector. (Masiukiewicz and Nowak, 2012) It is also necessary to further simplify the procedures for starting a business and to simplify the tax system. In the light of the World Bank report of 2012 concerning the taxation systems in the world, according to the criterion of their favor for entrepreneurs, Poland was classified in the second hundred to 183 countries. (World Bank, 2012) Therefore exists a need for a change in the accounting for the valuation of intangible assets. These assets despite the fact that often exceed the value of the assets are not disclosed in the financial statements.

\section{Conclusions}

The institutional support for SMEs in Poland is well developed; several barriers existing in Poland, however, hinders the further development of entrepreneurship. There are, however, taken by the Polish government action (e.g. Based on EU Directive) for the development of the SME sector. Guidelines and Directives of the European Union in recent years indicate the need for a positive approach to the problem of rescuing firms in difficulty (second chance policy), and the experiences of the recent subprime crisis point to the determination of parliaments, governments and central banks in preventing bankruptcy. In the area of institutional support for SME need the following activities:

- The need for further changes to the law bankruptcy and reorganization,

- The need to create institutions organizational and financial support for repair processes carried out by the company,

- Increasing access to external financing,

- Further development of education managers,

- Simplification of the tax system,

- The creation of a strong scientific center coordinating research, education and scientific information in this area.

A large share of SMEs in GDP and employment justifies continuing to support national and EU for the sector. The authors believe that there is a great need for research in this field, taking into account the specificities of different countries. This will allow comparative analyzes, the results of which transform into specific recommendations in business practice.

\section{References}

Altman, E. I., \& Hotchkiss, E. (2007). Trudnosci finansowe a upadtosc firm. Warszawa, PL: CeDeWu.

Centre for Strategy \& Evaluation Services. (2013). Evaluation of Market Practices and Policies on SME Rating. Washington: Panteia.

Communication from the Commission of 5 October 2007 to the Council, the European Parliament, the European Economic and Social Committee and the Committee of the Regions: Overcoming the stigma of business failure - for a second chance policy - Implementing the Lisbon Partnership for Growth and Jobs COM(2007) 584 final, October 5, 2007.

Council and EP Regulation No 805/2004 of April 21, 2004. (2004). Creating a European Enforcement Order for uncontested claims, Brussels.

Council and EP Regulation No 861/2007 of July 11, 2007. (2007). Establishing a European procedure for small claims, Brussels.

Dec, P. (2009). Upadlosci w Polsce i na swiecie. Kwartalnik Nauk o Przedsiebiorstwie, 1.

Dec, P. (2013). Statystyka upadlosci w Polsce i na swiecie w latach 1997-2011. In E. Maczynska (Ed.), Procesy upadlosciowe $i$ naprawcze $w$ Polsce na tle doswiadczen Unii Europejskiej. Warszawa, PL: Oficyna Wydawnicza SGH. 
Dec, P., \& Masiukiewicz, P. (2014). Measures of Success in Small and Medium-Sized Business in Poland. Kwartalnik Nauk o Przedsiębiorstwie, 1.

Elliot, D., Schwartz, E., \& Herbane, B. (2002). Business Continuity Management: A Crisis Management Approach. London, UK: Rutledge.

European Commission. (2004a). Communication from the Commission - Community guidelines on state aid for rescuing and restructuring firms in difficulty. Official Journal C 244 of October 1, 2004.

European Commission. (2004b). Communication from the Commission, Community Guidelines on State Aid for Rescuing and Restructuring Firm in Difficulty, 2004/C 244/02.

European Commission. (2004c). Regulation No 805/2004 of the European Parliament and of the Council of 21 April 2004 creating a European Enforcement Order for Uncontested European Commission (2007).Regulation No 861/2007 of the European Parliament and of the Council, creating a European Small Claims Procedure.

European Commission. (2007). Communication from the Commission to the Council, the European Parliament, the European Economic and Social Committee and the Committee of the Regions on "Overcoming the stigma of failure in business - for a second chance, COM (2007) 584, Brussels.

European Commission. (2011). The Second Chance of Bankruptcy Simplification of Bankruptcy Procedures and Support for a Fresh Start, Brussels.

European Parliament. (2000). Directive 2000/35/EC of European Parliament and the Council of 29 June 2000 on combating late payment in commercial transactions.

European Parliament. (2011). Directive 2011/7/EU of the European Parliament and of the Council of 16 February 2011 on combating late payment in commercial transactions, Brussels.

Gardawski, J. (2012). Ksztaltowanie sie klasy polskich przedsiebiorcow prywatnych: aspekty strukturalne i postawy. In A. Alinska (Ed.), Eseje o stabilnosci finansowej. Warszawa, PL: CeDewu.

Jasinski, L. J. (2008). Nobel z ekonomii. Warszawa, PL: Wydawnictwo Key Text.

Lukasiński, W. (2013). The Influence of Quality Management on the Management of an Organization. In S. Hitmar (Ed.), Management Trends in Theory and Practice. Zlina: Institute of Management by University of Zilina.

Masiukiewicz, P. (2010). Procesy naprawcze - szanse w Unii Europejskiej i bariery krajowe, Prace i Materialy Wydzialu Zarzadzania Uniwersytetu Gdanskiego, 4/2.

Masiukiewicz, P. (2011). Udzial bankow w tworzeniu drugiej szansy dla przedsiebiorstw. In A. Szelagowska (Ed.), Wspolczesna bankowosc korporacyjna. Warszawa, PL: CeDeWu.

Masiukiewicz, P. (2012). Rehabilitation Proceedings and Company Value. In S. Morawska (Ed.), Ekonomia i prawo upadlosci przedsiebiorstw. Zarzadzanie przedsiebiorstwem w kryzysie, Warszawa, PL: Oficyna Wydawnicza SGH.

Masiukiewicz, P. (2014). Funkcja sanacyjna banków wobec przedsiębiorstw. In S. Flejterski, A. Gospodarowicz (Ed.), Banki w społecznej gospodarce rynkowej. Warszawa, PL: Wyd. Zwiazek Banków Polskich.

Masiukiewicz, P., \& Nowak, M. (2012) Financial Leverage Models versus Bankruptcy Enterprises. Journal of International Scientific Publications. Economy \& Business, 4(6).

Orłowski, W., Pasternak, R., Flaht, K., \& Szubert, D. (2010). Procesy inwestycyjne $i$ strategie przedsiebiorstw w czasach kryzysu. Warszawa, PL: PARP.

Parliament and Council Directive No. 2011/7/EU on combating late payment in commercial transactions. (2011), Brussels.

Polityka drugiej szansy. Opinie przedsiebiorcow i ekspertow. (2011). Warszawa, PL: Instytut Badawczy ProPublicum i TNS Pentor.

Reakcje polskiego konsumenta na kryzys gospodarczy. (2009). T. Słaby (ed.), Warszawa, PL: Oficyna Wydawnicza SGH.

Schwartz, A. (2004). Normative Theory of Business Bankruptcy, Paper 32, Yale University.

World Bank. (2012). Paying Taxes 2012. Washington: PWC

Wstępne wyniki badania procesów upadłościowych i naprawczych. (2011). Warszawa, PL: TNS Pentor.

Żukowski, M. (2014) Małe i średnie przedsiębiorstwa w Polsce powinny być przedmiotem troski państwa i zainteresowania banków. In S. Flejterski, \& A. Gospodarowicz (Eds.), w: Banki w społecznej gospodarce rynkowej, red. Warsaw, PL: Wyd. Związek Banków Polskich. 